\title{
EFFECT OF MICROWAVE HEATING ON pH AND TERMITE RESISTANCE OF Pinus roxburghii WOOD
}

\author{
Pawan Kumar Poonia ${ }^{1,2, s}$, SadhnaTripathi ${ }^{2}$
}

In memoriam of Dr. Thomas C. MANNES

\begin{abstract}
This study investigated the effect of microwave treatment on wood $\mathrm{pH}$ and termite resistance. Pinus roxburghii heartwood was exposed to four different microwave intensities at $2450 \mathrm{MHz}$ frequency for 5 minutes. Preservative impregnation, $\mathrm{pH}$ variation and termite resistance of microwave-treated and control specimens were studied. Wood $\mathrm{pH}$ decreased from 4,6 (C1) to 3,9 (T4) and preservative uptake increased (i.e., 10,4 to $21,6 \mathrm{~kg} \cdot \mathrm{m}^{-3}$ ) with increasing microwave treatment intensities. However, microwave treatment had little effect on termite resistance.
\end{abstract}

Keywords: Dielectric treatment, durability, impregnation, Odentotermes obesus, pine.

\section{INTRODUCTION}

Chirpine (Pinus roxburghii) is distributed in sub-tropical to temperate regions. Pinus roxburghii wood is utilised for construction, packing cases, door and window frames and pulping (Luna 2005). The wood is non-durable and requires supplemental protection when used outdoors.

The heartwood of $P$. roxburghii is easily treated and performs better than many naturally durable heartwood species for variety of uses including cooling towers and marine conditions (Luna 2005). The $\mathrm{pH}$ of wood is one of the key chemical properties which affect a number of processes related to its utilisation such as excessive acidic nature of wood can be affect the fixation of preservative salts in wood (Sithole 2005) and may also affect its durability.

Microwave (MW) radiation is an innovative method for improving wood permeability and the drying rate in hardwoods. This method can also be used to produce new composite products and create opportunities for increasing timber durability by impregnation with preservatives (Torgovnikov and Vinden 2009, Dashti et al. 2012, Poonia et al. 2016). The effects of microwave treatment on $\mathrm{pH}$ and durability against termite of $P$. roxburghii wood remain unknown.

The aim of this study was to evaluate the effects of MW treatment of Pinus roxburghii wood on $\mathrm{pH}$, receptive to preservative treatment and termite resistance.

${ }^{1}$ College of Forestry, Sirsi, UAS Dharwad, Karnataka, India.

${ }^{2}$ Forest Research Institute, Dehradun,Uttarakhand, India. tripathis@icfre.org

*Corresponding author: pooniaforestry@gmail.com

Received: 01.01.2018 Accepted: 09.03.2018 


\section{MATERIALS AND METHODS}

\section{Preparation of wood specimens}

One Pinus roxburghii Sarg. tree (90 cm girth) was harvested from the grounds of the Forest Research Institute, Dehradun (latitude: $30^{\circ} 19^{\prime} \mathrm{N}$ and longitude: $78^{\circ} 04^{\prime} \mathrm{E}$ ). The freshly felled log was converted into small clear specimens measuring $3,8 \mathrm{~cm}$ (Width) $\times 3,8 \mathrm{~cm}$ (Thickness) $\times 15 \mathrm{~cm}$ (Length). The sawn specimens were randomly selected from heartwood portion of wood. The selected straight grain and defect free specimens were submersed in fresh water to maintain a green condition prior to MW treatment.

\section{Microwave treatment}

A $900 \mathrm{~W}$ microwave oven (model: 30SC3) was used at a frequency of $2450 \mathrm{MHz}$ for the experiment. Details of treatment are as follow:

Intensity of MW treatments: T1 $(95,57), \mathrm{T} 2(111,50), \mathrm{T} 3(127,42), \mathrm{T} 4\left(143,35 \mathrm{~W} / \mathrm{cm}^{2}\right)$ and $\mathrm{C} 1$ : Controls

MW treatment time: 5 Min

Total number of specimens: 90 including controls [Group-I: 30 specimens i.e., subjected to $\mathrm{pH}$ studies and Group-II: 60 specimens (30 were Microwave and 30 were MW cum Preservative treated) i.e., subjected for Termite mound test].

Replicates: six in each treatments and controls

\section{Moisture reduction}

Percent moisture reduction caused by MW treatment was calculated from the conditioned weight of the blocks before and after MW treatment.

$$
\text { Moisture reduction }(\%)=\frac{W_{1}-W_{2}}{W_{1}} \times 100
$$

Where, $W_{1}=$ Weight of specimens before MW treatment, and

$W_{2}=$ Weight of specimens after MW treatment.

\section{Wood pH}

Treated and control specimens for $\mathrm{pH}$ evaluation were converted into chips and $\mathrm{pH}$ of the wood samples was determined using the hot water extraction method described by Sinthole (2005).

\section{Preservative treatment}

Microwave treated and controls (C) specimens were subjected to preservative treatment with an aqueous solution of acid copper chromate (ACC) at $4 \%$ concentration using a full cell process i.e., an initial vacuum of $75 \mathrm{kPa}\left(25 \mathrm{in} \mathrm{Hg}\right.$ ) for 30 min followed by pressure $689,47 \mathrm{kPa}\left(100 \mathrm{lbs} / \mathrm{in}^{2}\right)$ for $1 \mathrm{~h}$. A Final vacuum of $75 \mathrm{kPa}$ (25 in $\mathrm{Hg}$ ) for $15 \mathrm{~min}$ was applied. Controls (C1) received no preservative treatment and served as references for the termite tests.

After treatment, specimens were weighed to determine the preservative retention (IS 401:2001). The amount of preservative solution absorbed by specimen (retention value $\mathrm{R}$ in $\mathrm{kgm}^{-3}$ ) was calculated as:

$$
R(\mathrm{~kg} / \mathrm{cuM})=\frac{G \times C \times 10}{V}
$$


Where; $\mathrm{G}$ is the weight of the preservative solution absorbed by the block $\left(\mathrm{W}_{2}-\mathrm{W}_{1}\right)$ in $\mathrm{gm}, \mathrm{C}$ is the concentration of the preservative solution (\%) and $\mathrm{V}$ is the volume of the test block in $\mathrm{cm}^{3}$.

\section{Termite mound test}

The samples were cut into test specimens $(100 \times 25 \times 6 \mathrm{~mm})$. The test specimens were buried at different places inside a termite mound of Odentotermes obesus (Rambur) in the beginning of month of May. Specimens were removed from the mound in November when activity of termites almost ceases due to fall in temperature. The specimens were visually examined for termite attack and reinstalled next year in month of May so as to have exposure to termites for two successive termite seasons. Specimens were cleaned off mud and debris, and evaluated visually to ascertain damage by termites, according to the following rating scale given in Table 1 (Shukla 1977).

Table 1. Scale used to assess degree of termites damage (Shukla 1977).

\begin{tabular}{|l|l|l|}
\hline Numerical rating & Symbol & Condition of sample \\
\hline 0 & $\mathrm{~N}$ & No attack, sample free from termite attack \\
\hline 0,5 & VSw & Trace attack, termite attack area less than 5\% of the surface. \\
\hline 1,0 & $\mathrm{Sw}$ & Light attack, $5-20 \%$ \\
\hline 2,0 & $\mathrm{Mw}$ & Moderate attack, $20-35 \%$ \\
\hline 3,0 & $\mathrm{Bw}$ & Heavy attack, $35-50 \%$ \\
\hline 5,0 & $\mathrm{Dw}$ & Very heavy attack, $>50 \%$ \\
\hline
\end{tabular}

\section{Statistics}

Statistical analysis was conducted using SPSS 16 version software. Retention and $\mathrm{pH}$ results of P. roxburghii at different MW intensities were compared using an analysis of variance (ANOVA) and Duncan's modified significant difference test at $\propto=0,05$.

\section{RESULTS AND DISCUSSIONS}

MW treated samples were compared with untreated samples for any visual defects such as checks or cracks caused by MW treatment. No checks or cracks were observed on MW treated P. roxburghii wood.

\section{Moisture reduction}

The initial moisture content (MC) of P. roxburghii wood before microwave treatment was $40,60 \%$ and decreased to 38,40 (T1) and 35,33\% (T4) respectively, after microwave treatment (Figure 1). 


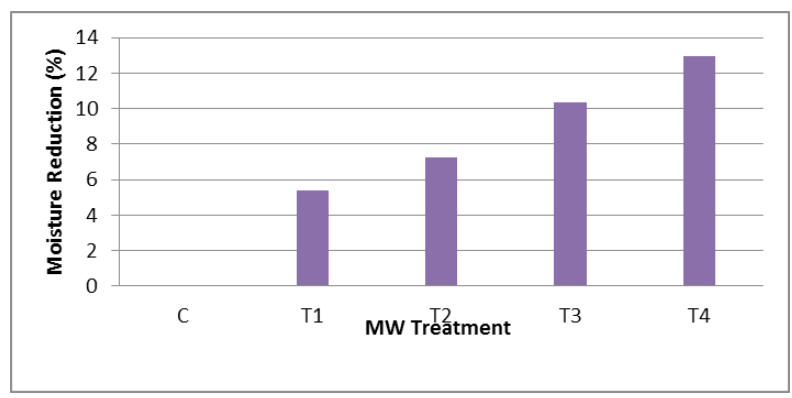

Figure 1. Mean moisture losses percentage in MW treated and untreated specimens of $P$. roxburghii $\{$ MSE 3,22 at $(\mathrm{p} \leq 0,05)$ level $\}$.

Increased MW treatment intensity resulted significant difference $(p \leq 0,05)$ in moisture reduction from the initial values. The intensity level of the MW energy had generated steam within the wood cell that resulted removal of MC from wood (Vinden et al. 2010). The removal of steam through pores could be seen visually when specimens were removed from microwave assembly.

\section{pH analysis of wood}

Wood $\mathrm{pH}$ steadily decreased with increasing microwave intensity and differed significantly between T2 $\left(111,50 \mathrm{~W} / \mathrm{cm}^{2}\right)$ and T3 $\left(127,42 \mathrm{~W} / \mathrm{cm}^{2}\right)$ MW treatments (Table 2).

Table 2. Effect of microwave treatment on $\mathrm{pH}$ of wood, preservative uptake and resistance to termite attack.

\begin{tabular}{|c|c|c|c|c|c|}
\hline \multirow{2}{*}{ Treatment } & \multirow{2}{*}{$\mathbf{p H}$} & $\begin{array}{c}\text { Retention } \\
\left(\mathbf{k g m}^{-3}\right)\end{array}$ & \multicolumn{2}{|c|}{$\begin{array}{c}\text { Average Numerical } \\
\text { Rating }\end{array}$} & $\begin{array}{c}\text { Final condition } \\
\text { of the samples }\end{array}$ \\
\cline { 4 - 5 } & & & $\mathrm{I}^{\text {st }}$ Season & II $^{\text {nd }}$ Season & \\
\hline Control $(\mathrm{C} 1)$ & $4,6^{\mathrm{a}}$ & - & 3,20 & 5 & Very heavy attack \\
\hline T1 & $4,4^{\mathrm{a}}$ & - & 3,15 & 5 & Very heavy attack \\
\hline T2 & $4,1^{\mathrm{b}}$ & - & 3,18 & 5 & Very heavy attack \\
\hline T3 & $4,1^{\mathrm{b}}$ & - & 3,12 & 5 & Very heavy attack \\
\hline T4 & $3,9^{\mathrm{b}}$ & - & 3,08 & 5 & Very heavy attack \\
\hline C + ACC & & $10,41^{\mathrm{c}}$ & 0 & 0 & No attack \\
\hline T1+ ACC & $17,53^{\mathrm{d}}$ & 0 & 0 & No attack \\
\hline T2+ ACC & $19,62^{\mathrm{e}}$ & 0 & 0 & No attack \\
\hline T3+ ACC & $20,16^{\mathrm{e}} \mathrm{f}$ & 0 & 0 & No attack \\
\hline T4+ ACC & $21,61^{\mathrm{f}}$ & 0 & 0 & No attack \\
\hline
\end{tabular}

Mean square Error of $\mathrm{pH}$ and retention is 0,06 and 0,88 at $(\mathrm{P} \leq 0,05)$ level respectively. Different letters denote significantly different groups.

Similar pH reductions have also been reported in Eucalyptus tereticornis wood by Poonia and Tripathi (2017) in MW treated wood. Niemz et al. (2010) and Chen et al. (2012) also found similar results in thermally modified wood. The $\mathrm{pH}$ decrease may be explained by the production of organic acids during thermal treatment, mainly by the degradation of hemicelluloses, as acetyl groups split off (Nuopponen et al. 2004). Phenolic carboxylic acid and 4-O-methyl-glucuronic and galacturonic acids are also produced as the result of wood hydrolysis adding to the acidity (Windeisen et al. 2007). 


\section{Retention of preservative}

The control (C) specimens had an average retention level of $10,41 \mathrm{~kg} / \mathrm{m}^{3}$, whereas samples treated using different MW intensities exhibited almost 2 fold increase in retentions (i.e. from 17,53 to 21,61 $\mathrm{kg} / \mathrm{m}^{3}$ ). Preservative retentions increased with increased MW intensity to a maximum of $21,61 \mathrm{~kg} / \mathrm{m}^{3}$ in samples exposed to $143,35 \mathrm{~W} / \mathrm{cm}^{2}$ whereas the lowest retention $\left(17,53 \mathrm{~kg} / \mathrm{m}^{3}\right)$ was found at 95,57 $\mathrm{W} / \mathrm{cm}^{2}$. Similar effects of MW-treatments were also reported by Treu et al. (2008) on Norway spruce (Picea abies), Ramezanpour et al. (2014) on fir wood and Poonia et al. (2016) on P. roxburghii wood. Thus results reveal that retention of preservative increase with increase in intensity.

\section{Termite mound test}

The control (C1) and microwave treated specimens were heavily attacked by termites in the first season. Attack continued and the samples were destroyed after a second season indicating that MW treatment provided no protection against termites. These results are in agreement with the results reported by Poonia and Tripathi (2017): MW treatment did not protect wood from termite attack. Similar results have also been found in thermally modified wood (Metsa-Kortelainen et al. 2011 and Duarte et al. 2012). The reason behind this non resistivity against termite is may be the change in chemical constituents and wood structure during microwave treatment. Thus, MW treatment attributes no resistance to wood against termite.

The specimens subjected to ACC preservative treatment at $689,47 \mathrm{kPa}\left(100 \mathrm{lbs} / \mathrm{in}^{2}\right)$ for $1 \mathrm{~h}$ were sound after two seasons of exposure. Hence, data exhibited significant higher protection when MW treatment was given with ACC at the different intensity. These results corroborate our previous findings (Poonia and Tripathi 2017), suggesting a synergistic effect between chemical and MW treatment for the improvement of termite durability. ACC preservative is effective even when specimens had not received any MW treatment. However, microwave treated wood resulted in remarkably high retention of preservative suggesting end use of wood even in drastic condition.

\section{CONCLUSIONS}

Microwave treatment of $P$. roxburghii wood significantly improved impregnation and reduced wood $\mathrm{pH}$, but did not improve termite's resistance. Since, Microwave treatment resulted substantial uptake of preservative in wood, similar experiments without pressure treatment may be conducted to reduce the processing time.

\section{ACKNOWLEDGEMENTS}

The authors are thankful to the Director, Forest Research Institute, Dehradun, India for providing facilities. The authors are also grateful to the staff of the Wood Preservation Discipline, F.R.I. Dehradun, for providing necessary help during experimental work.

\section{REFERENCES}

Chen, Y.; Fan, Y.; Gao, J.; Stark, N. M. 2012. The Effect of Heat Treatment on the Chemical and Color Change of Black Locust (Robinia Pseudoacacia) Wood Flour. BioResources 7(1): 1157-1170.

Duarte, S.; Welzbacher, C. R.; Duarte, M.; Nunes, L. 2012. Assessment of Thermally Modified Timber (TMT) through Subterranean Termites Feeding Behaviour. In Proceedings of the Sixth European 
Conference on Wood Modification, Ljubljana, Slovenia. 235-238.

Dashti, H; Tarmian, A; Faezipour, M; Hedjazi, S; Shahverdi, M. 2012. Effect of microwave radiation and pre-steaming treatments on the conventional drying characteristics of fir wood (Abies alba L.). Lignocellulose 1: 166-173.

Bureau of Indian standards. IS. 2001. Preservation of timber-code of practice. IS: 401. 2001. Manak Bhawan, New Delhi, India.

Luna, R.K. 2005. Plantation trees. International Book Distributors, Dehradun, India. 950p.

Metsa-Kortelainen, S.; Paajanen, L.; Viitanen, H. 2011. Durability of thermally modified Norway spruce and Scots pine in above-ground conditions. Wood Material Science and Engineering 1: $1-7$.

Niemz P.; Hofmann T.; Retfalvi T. 2010. Investigation of chemical changes in the structure of thermally modified wood. Maderas-Cienc Tecnol 12(2): 69-7.

Nuopponen, M.; Vuorinen, T.; Jamsa, S.; Viitaniemi, P. 2004. Chemical modifications in heat -treated softwood studied by FT-IR and UV resonance Raman (UVRR) spectroscopies. Journal of Wood Chemistry and Technology 24:13-26

Poonia, P. K.; Hom, S. K.; Sihag, K.; Tripathi, S. 2016. Effect of Microwave treatment on Longitudinal Air Permeability and preservative uptake characteristics of chirpine wood. MaderasCienc Tecnol 18(1): 125 - 132.

Poonia, P.K.; Tripathi, S. 2017. Effect of MW heating on pH and durability of Eucalyptus tereticornis wood. Journal of Tropical Forest Science 29(3): 389-394.

Ramezanpour, M.; Tarmian, A.; Taghiyari, H R 2014. Improving impregnation properties of fir wood to acid copper chromate (ACC) with microwave pre-treatment. iForest (early view): e1-e6 [online] available : $<$ http://www.sisef.it/iforest/contents/? id=ifor1119-007> [cited 2014-04-01]

Sithole, B. 2005. New method of measuring the $\mathrm{pH}$ of wood chips. Pulp and Paper Canada 106(11): 25-42.

Shukla, K.S. 1977. Preliminary investigations on the termite resistance of wood wool boards. $J$ Timber Development Association 23(1):21-23.

Torgovnikov, G.; Vinden, P. 2009. High intensity microwave wood modification for increasing permeability. Forest Prod J 59(4): 84-92

Treu A.; Rieche H.; Militz H. 2008. Spruce and pine heartwood treatment by means of microwave radiation IRG document no. IRG/WP 08-40411 the International Research Group on Wood Protection, Stockholm.

Vinden, P.; Torgovnikov, G.; Hann, J. 2010. Microwave modification of radiata pine railway sleepers for preservative treatment. Eur J Wood Prod 69(2):271-279.

Windeisen, E.; Strobel, C.; Wegener, G. 2007. Chemical changes during the production of thermo-treated beech wood. Wood Sci Technol 41: 523-536. 